\title{
Effects of Luteolin on Fetal Bovine Serum-induced Events in Cultured Rat Vascular Smooth Muscle Cells
}

Yong Lim*

\author{
Department of Clinical Laboratory Science, Dong-Eui Univerisity, Busan 614714, Korea
}

Received September 4, 2012 /Revised November 11, 2012 /Accepted December 12, 2012

\begin{abstract}
Cell cycle activation and progression in vascular proliferative disease represent potent therapeutic targets. Luteolin, which occurs as glycosylated forms in celery, green pepper, perilla leaf, and camomile tea, has demonstrated antimutagenic, antitumorigenic, antioxidant, and antiinflammatory properties. In this study, we investigated the effect of luteolin on the proliferation of primary cultured rat aortic vascular smooth muscle cells induced by $5 \%$ fetal bovine serum. Luteolin at concentrations of 5,20 , and $50 \mu \mathrm{M}$ significantly inhibited this proliferation by $29.6,50.8$, and $83.1 \%$, respectively. The incorporation of $\left[{ }^{3} \mathrm{H}\right]$-thymidine into DNA was also inhibited by $25.8,57.6$, and $81.0 \%$, respectively. Flow cytometry analysis of DNA content revealed that FBS-inducible cell cycle progression was blocked by luteolin. Luteolin showed no cytotoxicity in VSMCs in this experimental condition according to WST-1 assays. Luteolin may represent a potential anti-proliferative agent for treatment of angioplasty restenosis and atherosclerosis.
\end{abstract}

Key words : Luteolin, atherosclerosis, proliferation, vascular smooth muscle cell (VSMC)

\section{Introduction}

Vascular smooth muscle cells (VSMCs) in the arterial media are fully differentiated to play their physiological roles as regulators of vascular wall tension. They proliferate at low indices or persist in the G0 phase of the cell cycle [1,5]. Proliferation of VSMCs occurs in response to arterial injury and plays a crucial role in the pathogenesis of vascular disease, such as atherosclerosis, hypertension and restenosis [8]. An alternative approach to preventing the proliferation and migration of VSMCs may be to influence the downstream intracellular signaling events responsible for transducing the signals from the various growth factor receptors.

Flavonoids are naturally occurring polyphenolic compounds presented in a variety of fruits, vegetables and seeds. Flavonoids have many biological and pharmacological activities including antioxidative, antiinflammatory and anti-

\footnotetext{
*Corresponding author

Tel : +82-51-890-2684, Fax : +82-51-890-2622

E-mail : yonglim@deu.ac.kr

This is an Open-Access article distributed under the terms of the Creative Commons Attribution Non-Commercial License (http://creativecommons.org/licenses/by-nc/3.0) which permits unrestricted non-commercial use, distribution, and reproduction in any medium, provided the original work is properly cited.
}

tumor effects [4]. Luteolin (Fig. 1), a polyphenolic compound available in foods of plant origin, belongs to the flavone subclass of flavonoids, usually occurring as glycosylated forms in celery, green pepper, perilla leaf and camomile tea $[9,10]$. It has been reported to display antimutagenic, antiplatelet aggregation and anticancer effects [2,7].

In the present study, we investigated the antiproliferative effects of luteolin on primary cultured VSMCs stimulated by the administration of fetal bovine serum (FBS). Our results reveal that luteolin is a potential agent for the treatment of vascular disorders like atherosclerosis.

\section{Materials and Methods}

\section{Chemicals and reagents}

Luteolin (Sigma Chemical Co., MO, USA) was dissolved in dimethyl sulfoxide (DMSO) and further diluted in Dulbecco's Modified Eagle Medium (DMEM) without FBS. The cell culture materials were obtained from Gibco-BRL (Rockville, MD, USA), and other chemical reagents were from Sigma Chemical Co. $\left[{ }^{3} \mathrm{H}\right]$-thymidine was purchased Amersham Pharmacia Biotech (Buckingamshire, UK). Other chemicals were of analytical grade. 
<smiles>O=c1cc(-c2ccc(O)c(O)c2)oc2cc(O)cc(O)c12</smiles>

Fig. 1. Chemical structure of luteolin

\section{Cell culture}

Male Sprague-Dawley rats (Samtako Bio Korea Co., Ltd., Osan, Korea) weighing around $280 \mathrm{~g}$ were fed a normal chow diet and given water ad libitum. VSMCs were isolated by enzymatic dispersion as previously described [6] according to the modified method of Chamley et al. [3]. Cells were cultured in DMEM supplemented with 10\% FBS, $100 \mathrm{IU} / \mathrm{ml}$ penicillin, $100 \mathrm{\mu g} / \mathrm{ml}$ streptomycin, $8 \mathrm{mM}$ HEPES, $2 \mathrm{mM}$ L-glutamine at $37^{\circ} \mathrm{C}$ in a humidified atmosphere of $95 \%$ air and $5 \% \mathrm{CO}_{2}$ incubator. The purity of VSMCs culture was confirmed by immunocytochemically based on a-smooth muscle actin localization. The passage of VSMCs used in this experiment was 5-9.

\section{Cell counts}

VSMCs were seeded onto 12 -well culture plates at $1 \times 10^{5}$ cells $/ \mathrm{ml}$, and then cultured in DMEM containing $10 \%$ FBS at $37^{\circ} \mathrm{C}$ for $24 \mathrm{hr}$. Under these conditions, a cell confluence of $70 \%$ was reached. The medium was then replaced with serum-free medium containing luteolin $(5,20$ or $50 \mu \mathrm{M})$, and cells were then stimulated with 5\% FBS and trypsinized using trypsin-EDTA, and counted using a hemocytometer.

\section{DNA synthesis by $\left[^{3} \mathrm{H}\right]$-thymidine incorporation}

For $\left[{ }^{3} \mathrm{H}\right]$-thymidine incorporation experiments, VSMCs were seeded onto 24-well culture plates using conditions identical to those described above, and $1 \mu \mathrm{Ci} / \mathrm{ml}$ of $\left[{ }^{3} \mathrm{H}\right]$-thymidine was added to medium. Reactions were terminated by aspirating the medium and subjecting the cultures to sequential washes with phosphate-buffered saline (PBS) containing 10\% trichloroacetic acid and ethanol/ether $(1: 1, \mathrm{v} / \mathrm{v})$ on ice. The acid-insoluble $\left[{ }^{3} \mathrm{H}\right]$-thymidine was extracted into $250 \mu \mathrm{l}$ of $0.5 \mathrm{M} \mathrm{NaOH} /$ well, and this solution was mixed with a $3 \mathrm{ml}$ scintillation cocktail (Ultimagold,
Packard Bioscience, CT, USA). The mixed solution was quantified using a liquid scintillation counter (LS3801, Beckman, Düsseldorf, Germany), and $50 \mu$ of residual solution was measured using a BCA Protein Assay Reagent Kit (Pierce Biotechnology, Rockford, IL, USA).

\section{Cell viability assay}

For WST-1 assay (Premix WST-1, Takara, Japan), VSMCs were seeded in 96-well plates at $8 \times 10^{3}$ cells/well and pre-cultured in serum-free medium in the presence or absence of luteolin compounds for $24 \mathrm{hr}$. WST-1 reagent was added at $20 \mathrm{hr}$ and further incubated for $4 \mathrm{hr}$. Then the absorbance was determined in an ELISA at a wavelength of $450 \mathrm{~nm}$.

\section{Cell cycle progression analysis}

To estimate the proportion of cells in the various phases of the cell cycle, cellular DNA contents were measured by flow cytometry (FACS). Cells were harvested, fixed in $70 \%$ ethanol, and stored at $-20^{\circ} \mathrm{C}$. Cells were then washed twice with ice-cold PBS and incubated with RNase and propidium iodide (PI), a DNA-intercalating dye. Cell cycle phase analysis was performed using the FACSCalibur (Becton-Dickinson Co., San Jose, USA) and the proportion of cells within the G0/G1, S and G2/M phases was determined by analysis with ModFit LT V2.0 (Verity Software House, Topsham, USA).

\section{Statistical analysis}

The experimental results were expressed as mean \pm S.E.M. A one-way analysis of variance (ANOVA) was used for multiple comparison followed by Dunnett. Differences with $p<0.05$ were considered statistically significant.

\section{Results}

\section{Effect of luteolin on the proliferation of VSMCs}

The inhibitory effect of luteolin on proliferation of FBS-induced VSMCs was measured by cell number. The number of cells was significantly increased by $5 \%$ FBS for $24 \mathrm{hr}$. The FBS-induced cell numbers were significantly decreased by pre-treatment of luteolin for $24 \mathrm{hr}$ in a concentration-dependent manner. The percentage of inhibition exerted by 5, 20 and $50 \mu \mathrm{M}$ luteolin were 29.6, 50.8 and $83.1 \%$ respectively (Fig. 2). 


\section{Effect of luteolin on the DNA synthesis of VSMCs}

The effect of luteolin on the DNA synthesis of VSMCs was examined. Stimulation of VSMCs by $5 \%$ FBS potently increased $\left.{ }^{3} \mathrm{H}\right]$-thymidine incorporation from 1,803 to 15,979 $\mathrm{cpm} /$ well. luteolin significantly inhibited the FBS-induced DNA synthesis in a concentration-dependent manner, and the inhibition percentages were $25.8,57.6$ and $81.0 \%$ at the concentrations of 5, 20 and $50 \mu \mathrm{M}$, respectively (Fig. 3). No significant difference in viability was detected between control cells and those treated with luteolin $(5-50 \mu \mathrm{M})$ when examined by WST-1 assay (Fig. 4).

\section{Effect of luteolin on cell cycle progression}

Flow cytometric analysis (Table 1) demonstrated that luteolin affects cell cycle progression induced by $5 \%$ FBS. A primary culture of VSMCs was subjected to serum-deprivation for $24 \mathrm{hr}$, which resulted in approximately $87.8 \pm 075 \%$ of cells being synchronized in the G0/G1 phase. After incubation for $24 \mathrm{hr}$ in the presence of FBS, the percentage of cells in $S$ phase increased from $0.9 \pm 0.3$ to $18.2 \pm 1.3 \%$. In contrast, luteolin $(5-50 \mu \mathrm{M})$ blocked FBS-induced cell cycle progressions in a concentration-dependent manner (Table. 1). Luteolin $(5,20$ and $50 \mu \mathrm{M})$ reduced the percentage of FBS-stimulated cells in S phase to $14.2 \pm 1.2 \%(p<0.05), 9.0 \pm$ $0.4 \%(p<0.01)$ and $3.5 \pm 0.6 \%(p<0.01)$, respectively (Table. 1 ;

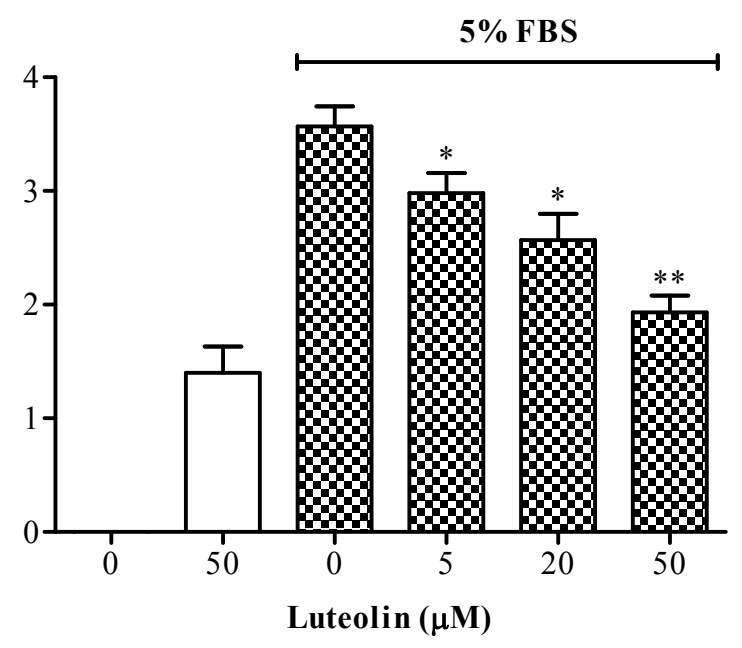

Fig. 2. Effect of luteolin on the FBS-induced VSMC proliferation. VSMCs were pre-cultured in serum-free medium at different concentrations $(5,20$ and $50 \mu \mathrm{M})$ of luteolin for $24 \mathrm{hr}$, and then exposed to 5\% FBS for $24 \mathrm{hr}$. Data are expressed as mean \pm S.E.M. from four different sets of experiments ${ }^{*} p<0.05,{ }^{* *} p<0.01$ vs. FBS-treated VSMCs. $\mathrm{n}=3$, duplicate cultures). This finding indicates that luteolin must act during early events in the cell cycle, since it is effective against DNA synthesis. Luteolin arrested significant numbers of cells in the G1 phase of the cell cycle, suggesting that its anti-proliferative effects in VSMCs are due to cell cycle arrest.

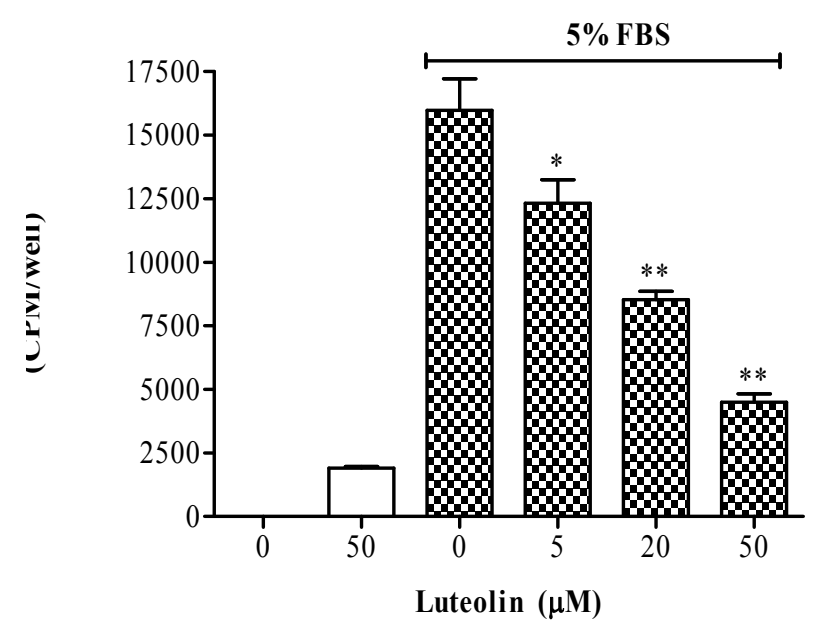

Fig. 3. Effect of luteolin on FBS-induced DNA synthesis. VSMCs were pre-cultured in serum-free medium at different concentrations $(5,20$ and $50 \mu \mathrm{M})$ of luteolin for $24 \mathrm{hr}$, and then exposed to 5\% FBS for $24 \mathrm{hr}$. $\left[{ }^{3} \mathrm{H}\right]$-thymidine incorporation assay was performed. Data are expressed as mean \pm S.E.M. from four different sets of experiments ${ }^{*} p<0.05,{ }^{* *} p<0.01$ vs. FBS- treated VSMCs.

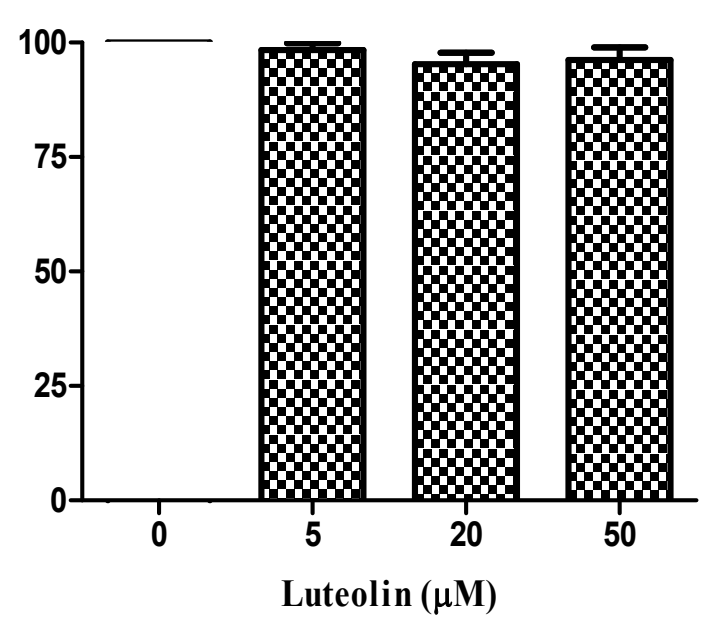

Fig. 4. Effect of luteolin on VSMCs viability. VSMCs were pre-cultured in serum-free medium at of different (5, 20 and $50 \mu \mathrm{M}$ ) concentrations of luteolin. After $24 \mathrm{hr}$, the cells were transferred to a hemocytometer. WST-1 assay was performed as described in materials and methods. 
Table 1. Effect of luteolin on FBS-stimulated cell cycle progression

\begin{tabular}{lccc}
\hline & G0/G1 & S & G2/M \\
\hline Control & $87.8 \pm 0.7$ & $0.9 \pm 0.3$ & $11.3 \pm 0.5$ \\
Luteolin $(50 \mu \mathrm{M})$ & $87.4 \pm 0.2$ & $1.0 \pm 0.4$ & $11.6 \pm 0.6$ \\
FBS & $70.0 \pm 0.9^{\#}$ & $18.2 \pm 1.3^{\#}$ & $11.8 \pm 1.5$ \\
FBS + Luteolin $(5 \mu \mathrm{M})$ & $73.5 \pm 1.2^{*}$ & $14.2 \pm 1.2^{*}$ & $12.3 \pm 0.9$ \\
FBS + Luteolin $(20 \mu \mathrm{M})$ & $78.4 \pm 1.2^{* *}$ & $9.0 \pm 0.4^{* *}$ & $12.5 \pm 0.4$ \\
FBS + Luteolin $(50 \mu \mathrm{M})$ & $83.7 \pm 0.7^{* *}$ & $3.5 \pm 0.6^{* *}$ & $2.7 \pm 0.9$ \\
\hline
\end{tabular}

The VSMCs were pre-cultured in the presence or absence of luteolin $(5-50 \mu \mathrm{M})$ in serum-depleted medium for $24 \mathrm{hr}$, and then VSMCs were stimulated by 5\% FBS. After $24 \mathrm{hr}$, individual nuclear DNA content was reflected by fluorescence intensity of incorporated propidium iodide. Each item is derived from a representative experiment, where data from at least 10,000 events were obtained. Results are means \pm SD, $n=3$. ${ }^{*} p<0.01$ vs. FBS-unstimulated cells (Control). ${ }^{*} \not<0.05,{ }^{* *} p<0.01$ vs. without luteolin in FBS-stimulated cells.

\section{Discussion}

Many growth factors induce the proliferation of VSMCs in vitro and in vivo. Among them, FBS and basic fibroblast growth factor are important regulators of VSMC behavior through their well-defined actions as potent chemoattractants and strong mitogens. Administration of these growth factors enhances intimal thickening after angioplasty in the rat, whereas injection of antibodies or use of antisense technology to block signal transduction by either of these growth factors potently inhibits postinjury intimal hyperplasia in the rat and restenosis in the pig, suggesting that VSMC growth plays an important role in these pathogenesis.

The aim of this study was to assess the effect of luteolin on the proliferation of serum-induced VSMCs. The antiproliferative effects of luteolin on VSMCs were examined by a direct cell counting assay. We found that luteolin is a potent inhibitor of VSMCs proliferation. The 5\% FBS-induced VSMCs proliferation was significantly decreased by pre-treatment of luteolin for $24 \mathrm{hr}$ in a dose-dependent manner (Fig. 2). The inhibitory effect of luteolin on incorporation of $\left[{ }^{3} \mathrm{H}\right]$-thymidine into the cells gradually declined as the delay between the treatments of VSMCs with luteolin and FBS (Fig. 3). In addition, the antiproliferative effect of luteolin on VSMCs was not due to cellular cytotoxicity, which were demonstrated by WST-1 assay (Fig. 4).

Recent studies [3] have emphasized the role of G-S events in the regulation of cell proliferation through complex stimulant and inhibitory signals driven by cyclin-dependent kinases and their inhibitors, respectively. To further investigate the pattern of the antiproliferative effect of luteolin, flow cytometry analysis was performed. As revealed by flow cytometry assay, the antiproliferative effect of luteolin was as- sociated with an accumulation of cells in G0/G1 phase of the cycle (Table 1). Since the observed accumulation in G0/G1 reflected a specific effect of luteolin on cell cycle progression rather than a decrease of cell number due to apoptosis.

Therefore, these results suggest that anti-proliferating agent could be an useful preventive or therapeutic agent for cardiovascular diseases including atherosclerosis, and luteolin can be one of these candidate agents.

\section{References}

1. Braun-Dullaeus, R. C., Mann, M. J. and Dzau, V. J. 1998. Cell cycle progression: new therapeutic target for vascular proliferative disease. Circulation 98, 82-89.

2. Casagrande, F. and Darbon, J. M. 2001. Effects of structurally related flavonoids on cell cycle progression of human melanoma cells: regulation of cyclin-dependent kinases CDK2 and CDK1. Biochem Pharmacol. 61, 1205-1215.

3. Chamley, J. H., Campbell, G. R., McConnell, J. D. and Groschel-Stewart, U. 1977. Comparison of vascular smooth muscle cells from adult human, monkey and rabbit in primary culture and in subculture. Cell Tissue Res. 177, 503-522.

4. Chen, Y. T., Zheng, R. L., Jia, Z. J. and Ju, Y. 1990. Flavonoids as superoxide scavengers and antioxidants. Free Radic. Biol. Med 9, 19-21.

5. Jackson, C. L. and Schwartz, S. M. 1992. Pharmacology of smooth muscle cell replication. Hypertension 20, 713-736.

6. Lim, Y., Kwon, J. S., Kim, D. W., Lee, S. H., Park, R. K., Lee, J. J., Hong, J. T., Yoo, H. S., Kwon, B. M. and Yun, Y. P. 2010. Obovatol from Magnolia obovata inhibits vascular smooth muscle cell proliferation and intimal hyperplasia by inducing p21Cip1. Atherosclerosis 210, 372-380.

7. Lu, H. W., Sugahara, K., Sagara, Y., Masuoka, N., Asaka, Y., Manabe, M. and Kodama, H. 2001. Effect of three flavonoids, 5,7,3', $4^{\prime}$-tetrahydroxy-3-methoxy flavone, luteolin, and quercetin, on the stimulus-induced superoxide generation and tyrosyl phosphorylation of proteins in human 
neutrophil. Arch Biochem Biophys. 393, 73-77.

8. Ross, R. 1993. The pathogenesis of atherosclerosis: a perspective for the 1990s. Nature 362, 801-809.

9. Shimoi, K., Okada, H., Furugori, M., Goda, T., Takase, S., Suzuki, M., Hara, Y., Yamamoto, H. and Kinae, N. 1998.
Intestinal absorption of luteolin and luteolin 7-O-beta-glucoside in rats and humans. FEBS Lett. 438, 220-224.

10. Shimoi, K., Saka, N., Kaji, K., Nozawa, R. and Kinae, N. 2000. Metabolic fate of luteolin and its functional activity at focal site. Biofactors 12, 181-186.

초록 : 소태아혈청으로 유도된 흰쥐 혈관평활근세포의 luteolin 효과

\section{임 용*}

(동의대학교 임상병리학과)

혈관 증식 질환에서 세포주기 활성화와 진행은 중요한 치료 목적으로 사용된다. Luteolin는 glycosylated 형태 로 샐러리, 후추, 들깨 잎 그리고 카밀레 차에 존재하며 항돌연변이, 항종양, 항산화 그리고 항염증을 나타낸다. 본 연구에서는 흰쥐 동맥으로부터 분리한 혈관평활근세포를 배양하여 소태아혈청으로 유도된 증식에서 luteolin 효과에 대해 조사했다. Luteolin이 $5 \%$ 소태아혈청으로 유도된 흰쥐의 혈관평활근세포 증식과 DNA 합성을 5,20 그리고 $50 \mu \mathrm{M}$ 에서 억제했다. 혈관평활근세포 증식을 각각 $29.6,50.8$ 그리고 $83.1 \%$ 억제했고 DNA 합성은 각각 25.8, 57.6 그리고 $81.0 \%$ 억제했다. 게다가, 유세포분석 결과 소태아혈청으로 유도된 혈관평활근세포의 세포주기 는 luteolin에 의해 차단되었다. 이러한 결과는 세포독성에 의해서도 나타날 수 있기 때문에 WST-1 분석으로 세 포독성을 확인한 결과 세포독성 없이 세포주기를 차단하는 효과임을 확인했다. 이상의 결과들은 luteolin이 혈관 스텐트와 동맥경화의 치료를 위한 의미있는 항증식 물질임을 보여준다. 